\title{
Compositions of Al-Based Quasicrystals Interpreted by Cluster Formulae
}

\author{
H. Chen, J.B. Qiang, Y.M. Wang And C. Dong* \\ Key Laboratory of Materials Modification (Ministry of Education), Dalian University of Technology \\ Dalian 116024, China
}

\begin{abstract}
It is known previously that bulk metallic glass compositions satisfy cluster formulae [cluster](glue atom) $)_{1,3}$ of 24 valence electrons as deduced from our cluster-resonance model. In the present work, it is further shown that compositions of Al-based binary and ternary quasicrystals are also explained by 24-electron cluster formulae of the types [icosahedron](glue atom) $)_{0,1}$, where the icosahedral cluster is identified from a corresponding crystalline approximant according to dense atomic packing and cluster isolation criteria, and the glue atom site is either vacant for an icosahedral quasicrystal or equal to one for a decagonal quasicrystal. Ternary quasicrystals are formulated with the same formulae as their basic binary ones but the icosahedron shell sites are substituted by third elements. The 24-electron cluster formulae are then the chemical and electronic structural units of quasicrystals, mimicking the molecular formulae of chemical substances.
\end{abstract}

DOI: 10.12693/APhysPolA.126.446

PACS: 61.44.Br, 36.40.-c, 71.20.Lp

\section{Introduction}

Atomic structures of alloy phases are generally described in terms of crystallography, i.e. atomic coordinates in unit cell scheme. However such a structural description is not suitable for complex structures with giant unit cell, not to mention for non-crystalline phases. As pointed out by Mackay and Finney [1], an alternative to crystallography might be clearly defined coordination polyhedra and their spatial packing.

Following the same strategy, we have developed the cluster-plus-glue-atom model to address the structural description of metallic glasses, quasicrystals (QCs) [2], and even normal compounds [3]. In this model, a phase structure is dissociated into a 1st-neighbor coordination polyhedron (i.e. cluster in our scheme) part and a 2nd-neighbor glue-atom part, or expressed in cluster formula [cluster](glue atom $)_{x}$. The cluster in the formula should exhibit the strongest bonding among all the local clusters present in a given structure, and it characterizes the principal short-range-order feature that can be presumably inherited in relevant structures. Close atomic packing and cluster isolation criteria have been used to identify the principal cluster [3]. By dense packing, we mean that the principal cluster should be the most densely packed part in the structure. Here the packing efficiency of a given cluster can be evaluated by comparing the radius ratios $R_{0} / R_{1}$ to that of an ideal cluster $R^{*}$ [4]: $\Delta=\left(R_{0} / R_{1}-R^{*}\right) / R^{*}$, where $R_{0}$ and $R_{1}$ are the atomic radii of the central atom and of the averaged shell atoms [5]. For the ideally close-packed icosahedron the $R^{*}$ ratio is 0.902 .

*corresponding author; e-mail: dong@dlut.edu.cn
The isolation criterion states that the principal cluster is generally not so much overlapped with neighboring clusters of the same kind. In periodic crystals, cluster overlaps are common, which reduce complete clusters into smaller effective ones [3]. However, it is difficult to judge a principal cluster only through its effective size as stated in Ref. [3] because at the same time the glue part should be minimized to show the dominating role of the principal cluster over the whole structure. Therefore we here amend the latter cluster isolation criterion by proposing a cluster-to-glue ratio, i.e., the number of atoms in the effective cluster to that in the glue part. A large ratio means high cluster isolation.

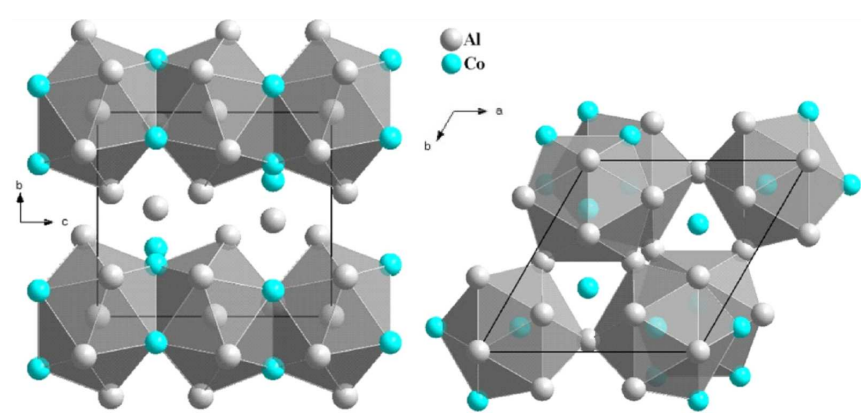

Fig. 1. Two types of icosahedra $\mathrm{Al}_{7} \mathrm{Co}_{6}$ (left) and $\mathrm{Co}_{3} \mathrm{Al}_{10}$ (right) in the $\mathrm{Al}_{5} \mathrm{Co}_{2}$ phase structure, projected along the $a$-axis and $c$-axis, respectively.

For QCs, the principal clusters are icosahedra adopted from crystalline approximants [6]. Take the $\mathrm{Al}_{5} \mathrm{Co}_{2}$ phase for example, which is an approximant of decagonal quasicrystals [7]. Two icosahedra $\mathrm{Al}_{7} \mathrm{Co}_{6}$ (the first element refers to the central atom) and $\mathrm{Co}_{3} \mathrm{Al}_{10}$ are present, as depicted in Fig. 1, which are respectively reduced to $\mathrm{Al}_{7} \mathrm{Co}_{3}$ (effective cluster size is 10 atoms) 
and $\mathrm{Co}_{1} \mathrm{Al}_{10 / 3}$ (effective cluster size is $13 / 3$ atoms) due to sharing of atoms between neighbouring clusters. Hence the $\mathrm{Al}_{5} \mathrm{Co}_{2}$ phase could be described by cluster formulae $\left[\mathrm{Al}_{7} \mathrm{Co}_{3}\right]\left(\mathrm{Al}_{3} \mathrm{Co}\right)=\mathrm{Al}_{10} \mathrm{Co}_{4}$ and $\left[\mathrm{Co}_{1} \mathrm{Al}_{10 / 3}\right] \mathrm{Co}_{1 / 3}=\mathrm{Al}_{10 / 3} \mathrm{Co}_{4 / 3}$, with the cluster-to-glue ratios being $10 / 4=2.5$ and $(13 / 3) /(1 / 3)=13$, respectively. This large difference singles out the icosahedron $\mathrm{Co}_{3} \mathrm{Al}_{10}$ as the principal cluster to describe the $\mathrm{Al}_{5} \mathrm{Co}_{2}$ phase. By utilizing the Goldschmidt atomic radii for $\mathrm{Al}(0.143 \mathrm{~nm})$ and $\mathrm{Co}(0.125 \mathrm{~nm})$, the packing efficiencies of $\mathrm{Al}_{7} \mathrm{Co}_{6}$ and $\mathrm{Co}_{3} \mathrm{Al}_{10}$ are obtained, respectively $(0.143 /((0.143 \times 6+0.125 \times 6) / 12)-0.902) / 0.902=18.3 \%$ and $(0.125 /((0.143 \times 10+0.125 \times 2) / 12)-0.902) / 0.902=$ $-1.0 \%$, with the latter icosahedron indeed being densely packed.

\section{24-electron cluster formulae of Al-based quasicrystals}

Recently, a cluster-resonance structural model has been developed to assess the electrons per atom ratio $(e / a)$ of ideal metallic glasses [8]: $\frac{e}{a}=\frac{1.25^{3} \pi}{3} \frac{1}{\rho_{a} r_{1}^{3}}$, with $\rho_{a}$ being the atomic density and $r_{1}$ being the radius of the principal cluster. The ideal atomic density is proportional to $Z / r_{1}^{3}$, which can be obtained by considering a super-cluster composed of densely packed unit clusters, with $Z$ being the number of atoms in unit cluster formula. Thus, the total number of valence electrons per unit cluster formula $e / u=(e / a) Z$ turned out to be constant, being close to 24 . Since for chemical molecules the total numbers of valence electrons in unit molecules follow usually the octet-electron rule, being 8 (e.g. $\mathrm{H}_{2} \mathrm{O}$ ) and its multiplications like 16 (e.g. $\mathrm{CO}_{2}$ ), 24 (e.g. $\mathrm{CaCO}_{3}$ ) and 32 (e.g. $\mathrm{H}_{2} \mathrm{SO}_{4}$ ), the cluster formulae here can be regarded as the "molecular" formulae because they are both compositional and electronic structural units, mimicking the molecular formulae of common chemical substances.

It is well accepted that quasicrystals are also stabilized by Hume-Rothery mechanism, just like metal- lic glasses. By using the principal icosahedral clusters identified from corresponding approximants using the close atomic packing and isolation criteria [3], compositions of binary Al-TM (transition metal) QCs were deciphered via the 24-electron cluster formulae [6]. The number of valence electrons per unit cluster formula $e / u$ could be determined by $e / u=(e / a) Z$, with $e / a=$ $\sum C_{i}(e / a)_{i}, C_{i}$ and $(e / a)_{i}$ being the atomic fraction and the electron concentration of the $i$-th element. Here we adopted $(e / a)_{\mathrm{Al}}=+3$ and a composition dependent $e / a$ assignment of TMs proposed by Stiehler et al. [9], $(e / a)_{\mathrm{TM}}=1-(100-x) / x, x$ being the atomic percentage of TM in the binary Al-TM-3d alloys. For instance, decagonal quasicrystals (DQCs) $\mathrm{A}_{77.6} \mathrm{Mn}_{22.4}$ is explained by $\left[\mathrm{Mn}_{2} \mathrm{Al}_{11}\right] \mathrm{Mn}_{1}=\mathrm{Al}_{78.6} \mathrm{Mn}_{21.4}(e / u=$ $\left.25.0,(e / a)_{\mathrm{Mn}}=1-(100-21.4) / 21.4=-2.7\right)$; DQCs $\mathrm{Al}_{72-73} \mathrm{Co}_{27-28}$ and $\mathrm{Al}_{76-70} \mathrm{Ni}_{24-30}$ are deciphered as $\left[(\mathrm{Co}, \mathrm{Ni})_{3} \mathrm{Al}_{10}\right](\mathrm{Co}, \mathrm{Ni})=\mathrm{Al}_{71.4}(\mathrm{Co}, \mathrm{Ni})_{28.6}(e / u=24.0$, $\left.(e / a)_{\mathrm{Co}, \mathrm{Ni}}=-1.5\right)$, where the icosahedral clusters are derived from crystalline approximants $\mathrm{Al}_{3} \mathrm{Mn}, \mathrm{Al}_{5} \mathrm{Co}_{2}$, and $\mathrm{Al}_{5} \mathrm{NiFe}$, respectively. Icosahedral quasicrystals (IQCs) $\mathrm{Al}_{86}(\mathrm{Fe}, \mathrm{Mn}, \mathrm{Cr})_{14}$ are formulated as $\left[\mathrm{TM}_{2} \mathrm{Al}_{11}\right]=$ $\mathrm{Al}_{84.6} \mathrm{TM}_{15.4}$, with $e / u=24.0\left((e / a)_{\mathrm{Fe}, \mathrm{Mn}, \mathrm{Cr}}=-4.5\right)$, with the icosahedra being obtained respectively from $\mathrm{Al}_{45} \mathrm{Cr}_{7}, \mathrm{Al}_{4} \mathrm{Mn}$, and $\mathrm{Al}_{13} \mathrm{Fe}_{4}$. Let us note that no glue atoms are required for IQCs, which can be regarded as random packing of icosahedra, thus supporting the icosahedral glass model $[10,11]$.

With the aid of the relevant composition rules of Al-TM binary QCs, ternary Al-based QCs (many ternary QCs compositions are tabulated in Ref. [2]) are revisited here and it will be shown that they are well explained by appropriate third elements substitutions of the same base binary formulae $\left[\mathrm{TM}_{2} \mathrm{Al}_{11}\right](\mathrm{TM}=\mathrm{Fe}, \mathrm{Mn}, \mathrm{Cr})$ for IQCs, and $\left[\mathrm{Mn}_{2} \mathrm{Al}_{11}\right] \mathrm{Mn}_{1}$ or $\left[\mathrm{TM}_{3} \mathrm{Al}_{10}\right] \mathrm{TM}_{1}(\mathrm{TM}=$ $\mathrm{Co}, \mathrm{Ni})$ for DQCs, as listed in Table.

24-electron formulae of Al-based QCs from the cluster-plus-glue-atom model.

TABLE IQCs stands for icosahedral quasicrystals and DQCs for decagonal ones.

\begin{tabular}{|c|c|c|c|c|c|}
\hline Experimental compositions & Cluster formulae & $Z$ & $r_{1}[\mathrm{~nm}]$ & $\begin{array}{l}\text { Empirical } \\
\rho_{a}\left[\mathrm{~nm}^{-3}\right]\end{array}$ & $e / u$ \\
\hline $\mathrm{IQC}-\mathrm{Al}_{62.5} \mathrm{Cu}_{24.5} \mathrm{Fe}_{13}$ & \multirow{4}{*}[\mathrm{TM}_{2}(\mathrm{Al}_{8}\mathrm{Cu}_{3})]{$=\mathrm{Al}_{61.5} \mathrm{Cu}_{23.1} \mathrm{TM}_{15.4}$} & \multirow{4}{*}{13} & 0.2736 & 67.8 & 19.2 \\
\hline $\mathrm{IQC}-\mathrm{Al}_{65} \mathrm{Cu}_{20} \mathrm{Mn}_{15}$ & & & 0.2634 & 67.5 & 21.6 \\
\hline $\mathrm{IQC}-\mathrm{Al}_{65} \mathrm{Cu}_{24} \mathrm{Cr}_{11}$ & & & 0.2656 & 67.6 & 21.0 \\
\hline $\mathrm{IQC}-\mathrm{Al}_{61.6} \mathrm{Cu}_{24.8} \mathrm{Ru}_{13.6}$ & & & 0.2758 & 65.8 & 19.2 \\
\hline $\mathrm{IQC}-\mathrm{Al}_{68.1} \mathrm{Cu}_{16.1} \mathrm{Ru}_{15.8}$ & \multirow{2}{*}[\mathrm{TM}_{2}\mathrm{Al}_{9}(\mathrm{Cu},\mathrm{Pd})_{2}]{$=\mathrm{Al}_{69.2}(\mathrm{Cu}, \mathrm{Pd})_{15.4} \mathrm{TM}_{15.4}$} & \multirow{2}{*}{13} & 0.2758 & 64.3 & 19.7 \\
\hline $\mathrm{IQC}-\mathrm{Al}_{70} \mathrm{Pd}_{15} \mathrm{Mn}_{15}^{a}$ & & & 0.2634 & 63.9 & 22.8 \\
\hline $\mathrm{IQC}-\mathrm{Al}_{68.7} \mathrm{Pd}_{21.7} \mathrm{Mn}_{9.6}$ & {$\left[\mathrm{MnPd}\left(\mathrm{Al}_{9} \mathrm{Pd}_{2}\right)\right]=\mathrm{Al}_{69.2} \mathrm{Pd}_{23.1} \mathrm{Mn}_{7.7}$} & 13 & 0.2634 & 63.2 & 23.0 \\
\hline $\mathrm{DQC}-\mathrm{Al}_{69.8} \mathrm{Pd}_{12.1} \mathrm{Mn}_{18.1}$ & {$\left[\mathrm{Mn}\left(\mathrm{Mn}_{0.5} \mathrm{Pd}_{0.5}\right) \mathrm{Al}_{10} \mathrm{Pd}\right] \mathrm{Pd}=\mathrm{Al}_{71.4} \mathrm{Pd}_{10.7} \mathrm{Mn}_{17.9}$} & 14 & 0.2634 & 64.0 & 24.5 \\
\hline $\mathrm{DQC}-\mathrm{Al}_{72} \mathrm{Co}_{15.5} \mathrm{Ni}_{12.5}$ & {$\left[\left(\mathrm{CoNi}_{2}\right) \mathrm{Al}_{10}\right] \mathrm{Co}=\left[\left(\mathrm{NiCo}_{2}\right) \mathrm{Al}_{10}\right] \mathrm{Ni}=\mathrm{Al}_{71.4} \mathrm{Co}_{14.3} \mathrm{Ni}_{14.3}$} & 14 & 0.2627 & 66.7 & 23.7 \\
\hline $\mathrm{DQC}-\mathrm{Al}_{64.3} \mathrm{Cu}_{21.9} \mathrm{Co}_{13.8}$ & {$\left[\left(\mathrm{CoCu}_{2}\right)\left(\mathrm{Al}_{9} \mathrm{Cu}\right)\right] \mathrm{Co}=\mathrm{Al}_{64.3} \mathrm{Cu}_{21.4} \mathrm{Co}_{14.3}$} & 14 & 0.2627 & 67.7 & 23.3 \\
\hline $\mathrm{DQC}-\mathrm{Al}_{66} \mathrm{Cu}_{17} \mathrm{Co}_{17}$ & {$\left[\mathrm{Co}\left(\mathrm{Cu}_{0.5} \mathrm{Co}_{0.5}\right) \mathrm{CuAl}{ }_{9} \mathrm{Cu}\right] \mathrm{Co}=\mathrm{Al}_{64.4} \mathrm{Cu}_{17.8} \mathrm{Co}_{17.8}$} & 14 & 0.2627 & 67.8 & 23.3 \\
\hline
\end{tabular}

${ }^{a}$ Ref. [16]. 
Since it is difficult to assign the $e / a$ contributions from TMs in ternary QCs, here we adopt an alternative way to estimate $e / u=(e / a) Z$ by use of the expression $\frac{e}{a}=\frac{1.25^{3} \pi}{3} \frac{1}{\rho_{a} r_{1}^{3}}$ from the cluster-resonance model. The atomic density $\rho_{a}$ is $\rho_{a}=N_{\mathrm{A}} \rho / M_{\mathrm{A}}$, where $N_{\mathrm{A}}=6.02 \times 10^{23} \mathrm{~mol}^{-1}$ is the Avogadro constant, $M_{\mathrm{A}}=\sum C_{i} M_{i}$ is the average molecular mass of the alloy, $C_{i}$ and $M_{i}$ represent the atomic fraction and atomic mass of the $i$-th element, $\rho$ is the mass density, which can be estimated by $\rho=\sum\left(C_{i} M_{i}\right) / \sum\left(C_{i} M_{i} / \rho_{i}\right)$ [12], where $\rho_{i}$ is the mass density of a pure element $i$. With the help of the estimated atomic density $\rho_{a}$, the radius of the cluster $r_{1}$ and the number of atoms in unit cluster formula $Z$, $e / u$ is then assessable.

Take the Al-Cu-Co DQC for example. As seen in the previous section, the icosahedron $\mathrm{Co}_{3} \mathrm{Al}_{10}$ derived from the $\mathrm{Al}_{5} \mathrm{Co}_{2}$ phase has been identified to be the principal icosahedron cluster. By referring to the cluster formula $\left[\mathrm{Co}_{3} \mathrm{Al}_{10}\right] \mathrm{Co}_{1}$ of binary $\mathrm{DQC}-\mathrm{AlCo}, \mathrm{DQC}-$ $\mathrm{Al}_{64.3} \mathrm{Cu}_{21.9} \mathrm{Co}_{13.8}$ [13] could be explained by substituting two $\mathrm{Co}$ and one $\mathrm{Al}$ atoms in the shell sites of the icosahedron $\mathrm{Co}_{3} \mathrm{Al}_{10}$ by three $\mathrm{Cu}$ atoms: [ $\left.\mathrm{CoCu}_{2} \mathrm{Al}_{9} \mathrm{Cu}\right] \mathrm{Co}_{1}=$ $\mathrm{Al}_{64.3} \mathrm{Cu}_{21.4} \mathrm{Co}_{14.3}$. The composition deviation (the composition distance in ternary phase diagram) is only 0.7 at.\%. By introducing atomic masses of $\mathrm{Al}\left(M_{\mathrm{Al}}=\right.$ $\left.26.982 \mathrm{~g} \mathrm{~mol}^{-1}\right), \mathrm{Cu}\left(M_{\mathrm{Cu}}=63.546 \mathrm{~g} \mathrm{~mol}^{-1}\right)$, and $\mathrm{Co}$ $\left(M_{\mathrm{Co}}=58.933 \mathrm{~g} \mathrm{~mol}^{-1}\right)$ along with the corresponding mass density $\left(\rho_{\mathrm{Al}}=2.7 \mathrm{~g} \mathrm{~cm}^{-3}, \rho_{\mathrm{Cu}}=8.93 \mathrm{~g} \mathrm{~cm}^{-3}\right.$ and $\left.\rho_{\mathrm{Co}}=8.9 \mathrm{~g} \mathrm{~cm}^{-3}\right)$ into the empirical mass density equation, $\rho=\sum(0.643 \times 26.982+0.214 \times 63.546+0.143 \times$ $58.933) / \sum(0.643 \times 26.982 / 2.7+0.214 \times 63.546 / 8.93+$ $0.143 \times 58.933 / 8.9)=4.4 \mathrm{~g} \mathrm{~cm}^{-3}$ is obtained, in good agreement with the measured density of $4.5 \mathrm{~g} \mathrm{~cm}^{-3}$ for the decagonal phase $\mathrm{Al}_{63} \mathrm{Si}_{2} \mathrm{Cu}_{20} \mathrm{Co}_{15}$ [14]. The atomic density $\rho_{a}=6.02 \times 10^{23} \times 4.4 /(0.643 \times 26.982+0.214 \times$ $63.546+0.143 \times 58.933)=67.7 \mathrm{~nm}^{-3}$. Using the average cluster radius $r_{1}=0.2627 \mathrm{~nm}$ of the icosahedron $\mathrm{Co}_{3} \mathrm{Al}_{10}$, the total number of valence electrons per unit cluster formula $e / u$ is then assessed: $e / u=$ $(e / a) Z=\frac{1.25^{3} \pi}{3} \frac{1}{67.7 \times 0.2627^{3}} \times 14=23.3$, which is close to 24. Another DQC- $\mathrm{Al}_{66} \mathrm{Cu}_{17} \mathrm{Co}_{17}$ [15] formulated as $\left[\mathrm{Co}\left(\mathrm{Cu}_{0.5} \mathrm{Co}_{0.5}\right) \mathrm{CuAl}_{9} \mathrm{Cu}\right] \mathrm{Co}_{1}=\mathrm{Al}_{64.4} \mathrm{Cu}_{17.8} \mathrm{Co}_{17.8}$ is explained using parameters $\rho_{a}=67.8 \mathrm{~nm}^{-3}, r_{1}=0.2627 \AA$, $Z=14$, which leads to $e / u=23.3$. The composition deviation is about 2.1 at.\%.

As summarized in Table, the cluster formulae of ternary Al-based QCs all conform to the 24-electron rule, with exceptions of $\mathrm{Al}-\mathrm{Cu}-\mathrm{Fe}$ and $\mathrm{Al}-\mathrm{Cu}-\mathrm{Ru}$ systems. The relatively low $e / u$ values may be due mainly to the overestimated cluster radius $r_{1}$, which is difficult to be determined when the shell atoms of the principal cluster are scattered over a wide range. Meanwhile, substitutions by third elements of different atomic radii may also introduce errors in the radius of the cluster $r_{1}$ for ternary Al-based QCs. For instance the twelve shell atoms of the $\mathrm{Fe}_{2} \mathrm{Al}_{11}$ icosahedron spread over a distance range from 0.2304 to $0.3476 \mathrm{~nm}$, with an averaged radius of
$0.2736 \mathrm{~nm}$, but 24 electrons would require a smaller $r_{1}$ value of $0.2538 \mathrm{~nm}$.

\section{Conclusions}

In this contribution, compositions of Al-based QCs have been deciphered by unified cluster formulae [icosahedron](glue) 0,1 according to the cluster-plus-glue-atom model and the cluster-resonance model. The icosahedra are identified from the corresponding Al-TM binary approximants according to dense atomic packing and cluster isolation criteria. Ternary Al-based QCs are all constructed by third elements substitutions on the shell sites of the icosahedra in the base binary cluster formulae. Furthermore, it has been verified that these unit cluster formulae conform to the 24-electron rule as deduced from the cluster-resonance model proposed for ideal metallic glasses, which implies that the cluster formulae of QCs are both the chemical and electronic structural units, mimicking the molecular formulae for chemical substances.

\section{Acknowledgments}

The present work is supported by Natural Science Foundation of China under grant number 51131002.

\section{References}

[1] A.L. Mackay, J.L. Finney, J. Appl. Crystallogr. 6, 284 (1973).

[2] C. Dong, Q. Wang, J.B. Qiang, Y.M. Wang, N. Jiang, G. Han, Y.H. Li, J. Wu, J.H. Xia, J. Phys. D, Appl. Phys. 40, R273 (2007).

[3] J.X. Chen, Q. Wang, Y.M. Wang, J.B. Qiang, C. Dong, Philos. Mag. Lett. 90, 683 (2010).

[4] D.B. Miracle, W.S. Sanders, O.N. Senkov, Philos. Mag. 83, 2409 (2003).

[5] Q. Wang, C. Dong, J.B. Qiang, Y.M. Wang, Mater Sci. Eng. A 449, 18 (2007).

[6] H. Chen, J.B. Qiang, Q. Wang, Y.M. Wang, C. Dong, Isr. J. Chem. 51, 1226 (2011).

[7] S. Song, E.R. Ryba, Philos. Mag. Lett. 65, 85 (1992).

[8] G. Han, J.B. Qiang, F.W. Li, L. Yuan, S.G. Quan, Q. Wang, Y.M. Wang, C. Dong, P. Häussler, Acta Mater. 59, 5917 (2011).

[9] M. Stiehler, J. Rauchhaupt, U. Giegengack, P. Häussler, J. Non-Cryst. Solids 353, 1886 (2007).

[10] D. Shechtman, I.A. Blech, Metall. Trans. A 16, 1005 (1985).

[11] P.W. Stephens, A.I. Goldman, Phys. Rev. Lett. 56, 1168 (1986).

[12] O.N. Senkov, D.B. Miracle, V. Keppens, P.K. Liaw, Metall. Mater. Trans. A 39, 1888 (2008).

[13] S. Taniguchi, E. Abe, Philos. Mag. 88, 1949 (2008).

[14] N.K. Mukhopadhyay, G.C. Weatherly, J.D. Embury, Mater. Sci. Eng. A 315, 202 (2001).

[15] J. Guo, E. Abe, T. Sato, A.P. Tsai, Jpn. J. Appl. Phys. 38, L1049 (1999).

[16] A.P. Tsai, A. Inoues, Y. Yokoyama, T. Masumoto, Philos. Mag. Lett. 61, 9 (1990). 